\title{
Amygdaloid Kindling and the GABA System
}

\author{
Michael S. Myslobodsky and Elliot S. Valenstein \\ Department of Psychology and Neuroscience Laboratory, University of \\ Michigan, Ann Arbor, Michigan 48109
}

\begin{abstract}
Summary: The effect of increased brain GABA levels on fully kindled amygdala seizures was investigated in Long-Evans rats. The newly synthesized GABA-transaminase inhibitor, $\gamma$-acetylenic GABA (GAG) administered on four consecutive days $(100 \mathrm{mg} / \mathrm{kg}$, followed by $50 \mathrm{mg} / \mathrm{kg}$, i.p.) was found to either significantly reduce, or eliminate entirely, the behavioral seizures normally produced by amygdala stimulation. The effect is seen after the first injection of GAG although its magnitude was greater on subsequent days. Behavioral seizures reappeared 2 to 3 days after termination of GAG treatment. The duration of electrographic seizures (self-sustained amygdala afterdischarge) was either unchanged or greater on the first day of GAG treatment, but was briefer on subsequent days. The duration of afterdischarges returned to normal levels 1 to 2 days earlier than the behavioral seizures after the termination of GAG. Picrotoxin $(1.5-2 \mathrm{mg} / \mathrm{kg}$, i.p.) did not antagonize either electrographic or behavioral effects of inhibition produced with GAG. Electrical stimulation of amygdala delivered during the initial sedation stage induced by picrotoxin resulted in further regression of kindled seizures in the majority of animals. Although in doses employed, GAG alleviates amygdaloid-kindled seizures its use requires caution in view of its ability to reduce arousal level.
\end{abstract}

Convulsive disorders are commonly thought to result from inadequate neural inhibition. Pharmacological therapy directed to strengthen this inhibition is generally perceived as a desirable maneuver in order to antagonize the initiation, development, and propagation of focal and generalized seizures. Correspondingly, the major candidate for the inhibitory brain transmitter, $\gamma$-aminobutyric acid (GABA), which supposedly mediates pre- and postsynaptic inhibition (Krnjevic, 1971, 1974; Roberts et al., 1970), is implicated in epilepsy, whereas GABAergic compounds are per- ceived to be potential anticonvulsants (Meldrum, 1975).

Over the past several years, efforts have been made to elevate brain GABA content by blocking the GABA catabolizing enzyme, GABA-transaminase (GABA-T) (4-aminobutyrate: 2-oxoglutarate aminotransferase). Recently, the role of the newly synthesized GABA-T inhibitor, $\gamma$ acetylenic GABA (GAG) and $\gamma$-vinyl GABA (GVG), were examined in several studies (Jung et al., 1977a,b; Schechter et al., 1977a,b). Administered systemically, these compounds produced a sixfold in-

Received August 8, 1979.

Key words: Amygdala-Kindling-GABA-Picrotoxin-GAG-Seizures.

Permanent address for Professor Myslobodsky is: Psychobiology Research Unit, Department of Psychology, Tel-Aviv University, Tel-Aviv, Israel. 
crease in GABA brain content (Jung et al., $1977 a, b)$ and have been reported to block audiogenic epilepsy in mice (Schechter et al., $1977 a, b)$ and to suppress natural photosensitive epilepsy in the baboon (Meldrum and Horton, 1978). In contrast, Cooper et al. (1979) have seen only incomplete protection against audiogenic seizures during alcohol withdrawal in mice after moderate doses and even an increased susceptibility to seizures after higher doses of GABA-T inhibitors. Wood et al. (1977) found certain delays in hyperbaric oxygen-induced seizures in mice under GAG, although they reported no correlation between the large increase in brain GABA content and the anticonvulsant action of the compound.

In a recent pilot study Myslobodsky et al. (1979) reported that the effect of GABA-T inhibitors ranged from aggravation of metrazol-activated convulsions to the amelioration of seizures developed during the so-called amygdala kindling produced by repeated daily electrical stimulation (Goddard, 1967). Actually, little is known about the role of the GABAergic system in kindled epilepsy (see Wada, 1977 for review) and the present study was an attempt to replicate in another strain of rats earlier preliminary observations and to extend and quantify the available data. In addition, anticipating the alleviation of kindled seizures by GAG, the GABA antagonist, picrotoxin, was chosen as a contrasting drug in order to shed further light on the mechanisms underlying effects produced by GABA-T inhibitors.

\section{METHODS}

\section{Experimental Animals}

Naive, male pigmented Long-Evans rats (Charles River Laboratories, Wilmington, Mass.) ranging in weight from 250 to $350 \mathrm{~g}$ at the start of the experiment were used. Animals were housed individually in a temperature-regulated vivarium. Water and food were available ad libitum. Day-night cycle $(14 / 10)$ was maintained by artificial lighting.

Electrodes were implanted in the amygdala, using standard stereotaxic techniques (coordinates: $2.5 \mathrm{~mm}$ posterior to bregma, $4.5 \mathrm{~mm}$ lateral, $8.0 \mathrm{~mm}$ below dura, with skull level between bregma and lambda) 7 to 8 days before the beginning of the kindling sessions. The electrodes consisted of two $0.20 \mathrm{~mm}$ diam twisted " 316 " stainless steel wires, bare of teflon insulation only at the adjacent tips. The electrodes were attached to microminiature pins (Winchester CD8456), which were fixed to the skull with acrylic dental cement reinforced by four jeweler's screws.

Three animals were implanted with bilateral cortical, recording electrodes. Holes for electrodes, located over the visual cortex, were drilled with care to avoid damage to the dura. A hole for an indifferent electrode was drilled in the midline over the cerebellum. The cortical and indifferent electrodes consisted of approximately 1.0 $\mathrm{mm}$ silver balls (produced by melting insulated silver wire, $0.1 \mathrm{~mm}$ diam) positioned on the dura. The wire was presoldered to microminiature pins, which were cemented to the skull.

\section{Procedure and Apparatus}

The rat was connected to a cable and placed in the observation chamber $(20.5 \mathrm{~cm}$ $\times 26.5 \times 42.5 \mathrm{~cm}$ ). Kindling stimulation was performed according to the "suprathreshold" procedure of Racine (1972) and consisted of a 1-sec duration train of $50.0 \mu \mathrm{A}, 60 \mathrm{~Hz}$ current. Electrical stimulation was delivered three times a day (with 3 $\mathrm{hr}$ intervals) until the development of motor manifestations and continued at a rate of one per day, every day. EEG monitored for afterdischarge was taken regularly before, during, and after the electrographic seizure. The duration of the postictal period was recorded as long as the behavioral excitation lasted.

Drug treatment was initiated after the 
animals were considered fully kindled, using as a criterion the attainment of stage 5 (Racine, 1972; see below) seizures on at least 5 consecutive days. The drug treatment period lasted 4 days and began with $100 \mathrm{mg} / \mathrm{kg}$ of GAG given at 8 to 9 a.m. and followed by $50 \mathrm{mg} / \mathrm{kg}$ administered at the same time on the 3 subsequent days. During the treatment period the animals were stimulated electrically twice a day, at 4 to 5 and $24 \mathrm{hr}$ after the drug administration.

The drug doses and time between pretreatment and EEG sessions were chosen on the basis of findings indicating that GABA brain levels are maximal 4 to $12 \mathrm{hr}$ after GVG and GAB administration and remain supernormal at $24 \mathrm{hr}$ (Jung et al., 1977a,b; Schechter et al., 1977a,b; Wood et al., 1977). On the last day of this treatment animals with inhibited or regressed seizures were injected with picrotoxin (1.5-2.0 $\mathrm{mg} / \mathrm{kg}$ ) immediately after the completion of the kindling test in an attempt to antagonize the seizure suppression produced by GAG. A second kindling test was performed 2 to 3 $\mathrm{hr}$ after the picrotoxin injection. This second test was performed, therefore, 6 to $7 \mathrm{hr}$ after the last injection of GAG.

In order to assess the recovery dynamics and to determine the importance of further stimulation in this process, the subjects were randomly assigned into two equal groups. In the first group, the kindling sessions were continued every day after drug treatment termination until at least three successive stage 5 seizures occurred. In the second group, kindling sessions were discontinued for a 2 to 3 day interval after drug treatment, renewed after this interval and likewise continued until at least three consecutive stage 5 seizures occurred.

In an auxiliary study conducted with five rats, an estimate of the behavioral and EEG responses to picrotoxin $(1.0-4.0 \mathrm{mg} / \mathrm{kg}$ ) alone was made. After injection of picrotoxin the behavioral and EEG changes were monitored. Special emphasis was given to the time of appearance of changes in pos- ture, motility, ability to rear with forelimbs hanging free, and to epileptiform activity (isolated jerks, multiple jerks, grand mal seizures, postictal behavior).

\section{Drugs}

$\gamma$-Acetylenic GABA (Merrell Research Center, Cincinnati, Ohio) and picrotoxin (Abbott Laboratories, Toledo, Ohio) were dissolved in sterile saline and injected intraperitoneally.

\section{Definitions}

The term seizure refers to behavioral convulsions unless specifically mentioned otherwise. Electrographic convulsions in kindled animals are denoted as afterdischarges. Postictal excitation is a behavioral syndrome and in kindled rats it consists of an intense startle reaction, jumping, and struggling when an attempt is made to handle them or when they are touched at the base of the tail, neck or body. Undisturbed rats do not display postictal excitation.

\section{Data Reduction and Scoring}

The pattern of convulsions was noted and classified according to the stages described by Racine (1972). Briefly, this classification consists of the following: Stage 0 , no motor response; stage 1 , mouth and facial movements; stage 2, head nodding; stage 3 , forelimb clonus; stage 4 , rearing; stage 5 , rearing and falling with loss of postural control. This classification scheme was supplemented with stage 6 , multiple (more than one) rearing and falling. EEG recording was compared with the event recording made on the same paper to denote the duration of the seizure and the postictal excitation (Fig. 1).

\section{RESULTS}

\section{Effects of GAG on Kindled Seizures}

All animals exhibited a stage 5 or 6 seizure within 6 to 12 stimulation sessions $(8.8$ $\pm 4.25 \mathrm{SD}$ ) and the pre-GAG baseline crite- 


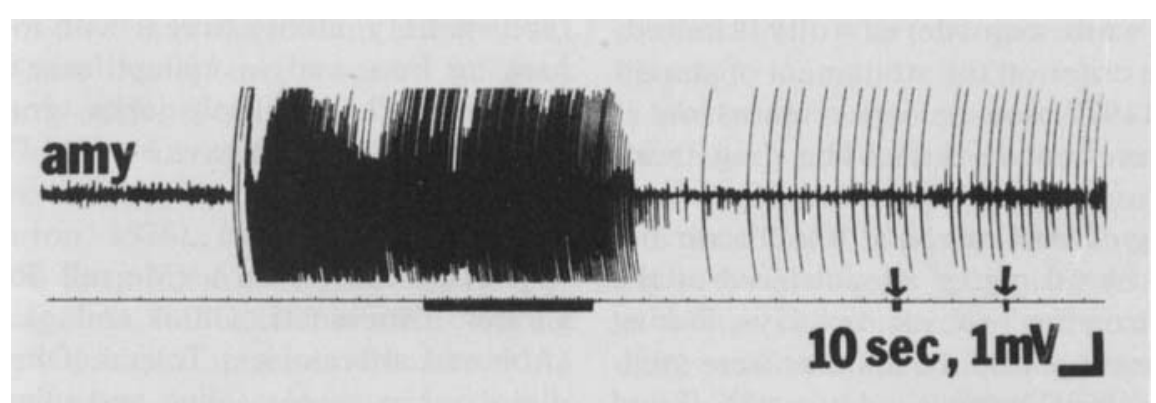

FIG. 1. An example of amygdaloid self-sustained afterdischarge and postictal spiking with the event recording (second channel) indicating the duration of the behavioral seizure and postictal excitatory period (arrows).

rion (five consecutive stage 5 seizures) was reached at a mean of $18.25(8.98 \mathrm{SD})$ sessions. GAG treatment produced noticeable changes in the animals' behavior, consisting of reduced motility and exploratory activity, arousal decrement, slight ataxia, and somnolence. Although these effects were not quantified, evidence of toxicity was not always as evident after the third injection, when animals exhibited normal exploration of the test cage $24 \mathrm{hr}$ after an injection, but they tended to be less mobile and more somnolent than untreated animals during the test administered $4 \mathrm{hr}$ after an injection. GAG administration resulted in a varying degree of synchronization of EEG that tended to build up with successive injections. The major EEG effect produced by GAG was a burst of paroxismal waves or wave-spike discharges of 3 to $5 \mathrm{~Hz}$ as described elsewhere (Myslobodsky et al., 1979; Valenstein and Myslobodsky, submitted).

The effects of repeated GAG administration on the seizure intensity and the afterdischarge are shown in Fig. 2. It can be seen from the figure that there is a considerable regression in the seizure intensity stage after GAG treatment (Fig. 2B). In 8 of the 12 animals tested after five consecutive stage 5 or 6 seizures, a stage 0 response occurred at least once during GAG treatment. Only in five animals was any stage 5 seizure displayed during the 4 days of drug

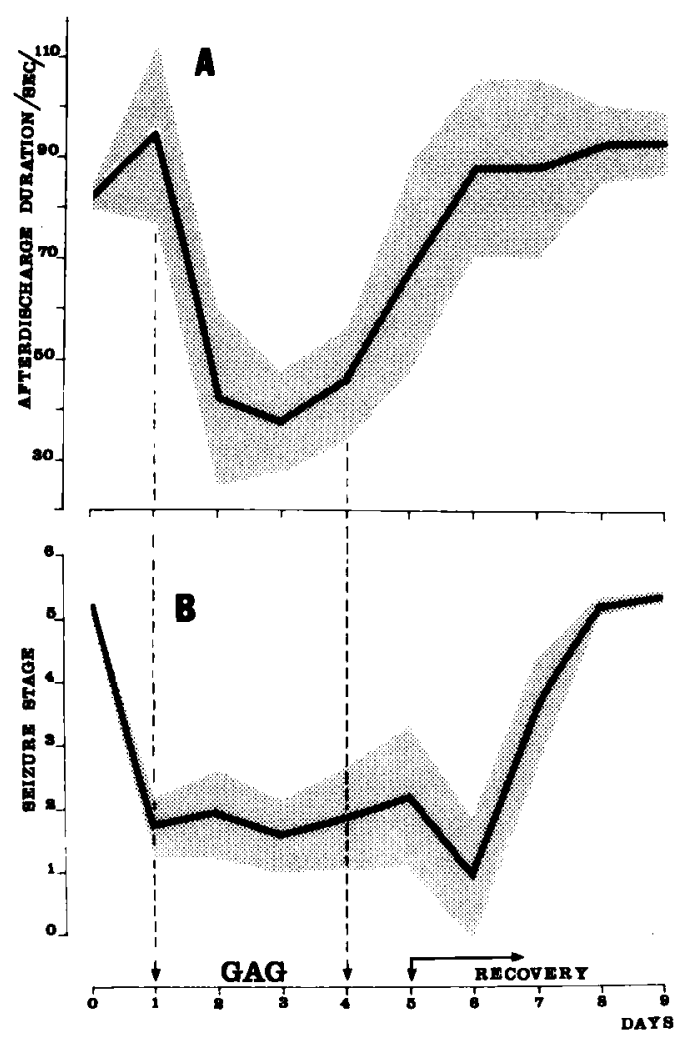

FIG. 2. Duration of the afterdischarge (A) and behavioral seizure stage (B) as a function of GAG treatment time course. The ordinate in $A$ represents the afterdischarge duration in sec $\pm \mathrm{SD}$ (shaded area); the ordinate in $\mathrm{B}$ represents seizure stage according to Racine (1972) with stage 6 added to denote multiple rearing and falling. Pre-drug duration of the afterdischarge and seizure stage is represented by the average of the five days preceding the first GAG administration. 
treatment and these were seen on less than one-half the tests. Moreover, these seizures were noticeably different from normal stage 5 seizures in that they occurred after a long latency, they had a shorter duration, and they were seldom followed by postictal excitation.

An attempt was made to induce more severe seizures in animals during the period of GAG treatment, by increasing the stimulation duration from 0.5 to $3.0 \mathrm{sec}$. Only in seven trials of the 21 conducted with five rats did this long-duration stimulus produce a stage 5 seizure. In general, the regression of seizures appeared to be greater at $4 \mathrm{hr}$ after GAG treatment than $24 \mathrm{hr}$ (data not shown). Paradoxically, the afterdischarge duration either did not change, or it actually increased during the first day of drug administration. Its duration decreased during subsequent treatment and recovered within 1 to 2 days after GAG administration was discontinued (Fig. 2A), anticipating the full recovery of behavioral seizures by a day or two.

In the six animals tested daily after the termination of GAG injection, behavioral seizures were regressed or totally absent for 2 to 3 days. This effect is probably due to residual supranormal levels of brain GABA. The gradual return to more severe seizures does not seem to depend on the stimulation trials as the other six rats, which were given an interval of 2 to 3 days without stimulation after the termination of GAG treatment, exhibited stage 5 to 6 seizures on the first post-drug test.

Effects of GAG on the duration of stage 5 fits and the postictal excitation (jumping, running, biting) observed during handling is shown in Table 1. It can be seen from this table that the duration of the occasional stage 5 seizures that occurred did not change, but these were followed by a reduction in postictal excitation. This reduction showed some tendency to persist into the post-drug recovery period, remaining somewhat lower in the recovery period.

\section{Effect of Picrotoxin}

Although picrotoxin is generally regarded as belonging to a group of analeptic compounds (Wang and Ward, 1977) its excitatory action occurs with a considerable delay. In fact, the first effect to develop after the administration of 1.5 to $4.0 \mathrm{mg} / \mathrm{kg}$ of picrotoxin is an inhibitory one, characterized behaviorally by a stage of sedation and ataxia. Electrographically, this stage is characterized by a buildup of EEG synchronization culminating with $7 \mathrm{~Hz}$ spindle-shaped paroxismal bursts of spindles and wavespikes (Fig. 3A). This stage lasts for 5 to $20 \mathrm{~min}$ and, with doses $2 \mathrm{mg} / \mathrm{kg}$ and higher, is terminated by the development of isolated head or head-body myoclonic jerks classified as stage 2 of the picrotoxin effect. Electrographically, stage 2 is characterized by a gradual replacement of the relatively smooth waxing and waning shape of the spindles by spindles preceded by a single spike, which regularly accompanied the appearance of a myoclonic jerk (Fig. 3B). The frequency of the spindles also decreased to 4 to $5 \mathrm{~Hz}$ during stage 2 . Stage 3 was designated when the animal displayed multiple, myoclonic jerks corresponding to the development of 2 to 3

TABLE 1. Duration of behavioral seizures and latency and duration of postictal excitation (mean and SEM)

\begin{tabular}{lccc}
\hline State & $\begin{array}{c}\text { Behavioral } \\
\text { seizure } \\
\text { duration }\end{array}$ & $\begin{array}{c}\text { Postictal } \\
\text { excitation } \\
\text { latency }\end{array}$ & $\begin{array}{c}\text { Postictal } \\
\text { excitation } \\
\text { duration }\end{array}$ \\
\hline Pre-drug & $37.20 \pm 2.38$ & $27.28 \pm 1.51$ & $92.69 \pm 7.51$ \\
GAG & $37.5 \pm 4.02$ & $34.14 \pm 4.9$ & $21.76 \pm 7.49$ \\
Recovery & $40.87 \pm 1.88$ & $29.5 \pm 1.54$ & $60.63 \pm 9.57$ \\
\hline
\end{tabular}




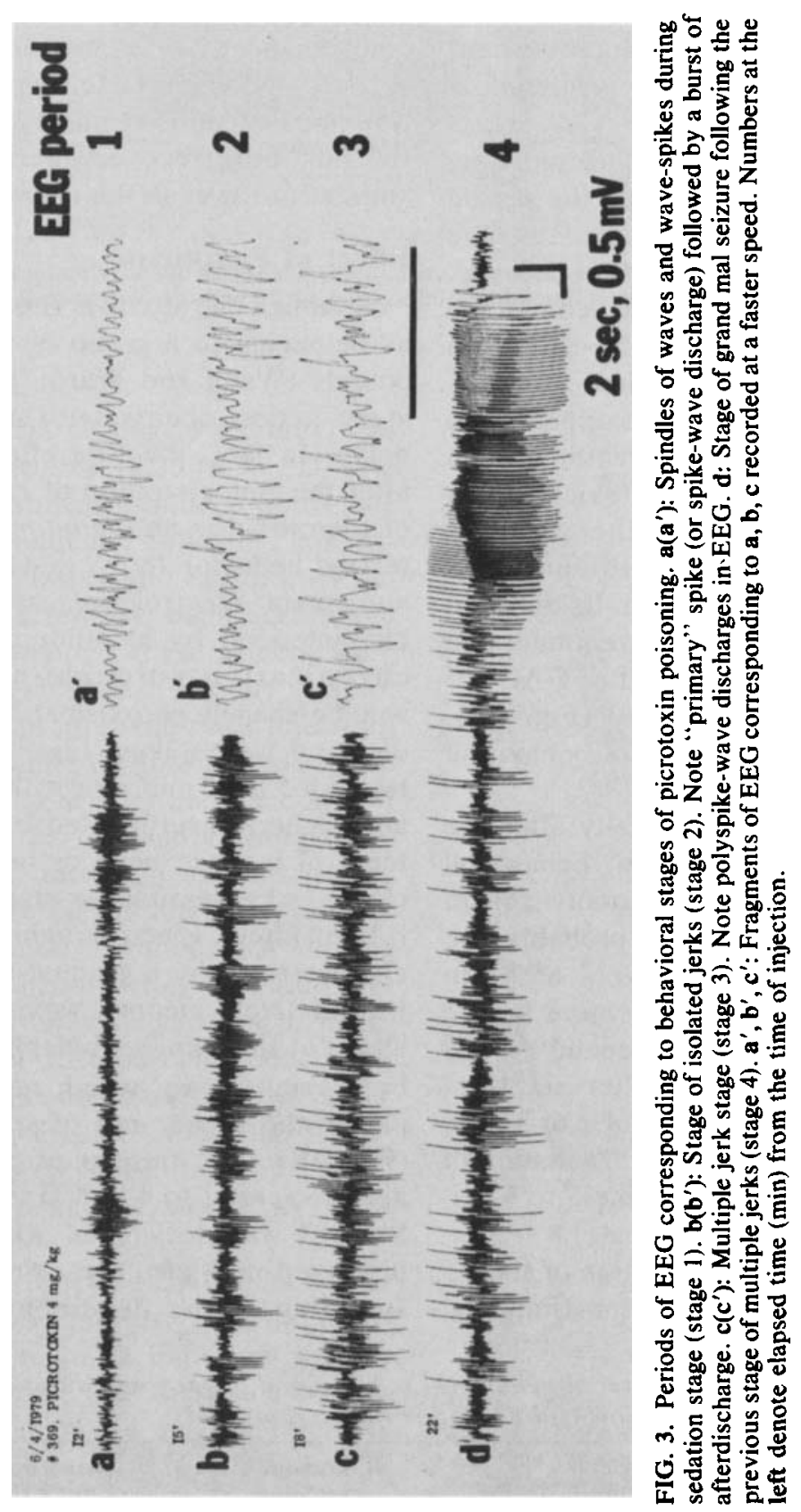


spikes at the beginning of spindles, that either assumed the form of an afterdischarge (in the mild cases) (Fig. 3C) or the EEG was entirely disorganized, containing numerous polyspikewave discharges leading eventually to a behavioral and electrographic grand mal convulsion (stage 4) (Fig. 3D). Depending on the sensitivity of the animal, stage 4 could develop with a dose of $2 \mathrm{mg} / \mathrm{kg}$, although it usually requires higher doses than were explored in the present study.

Figure 4 demonstrates that picrotoxin administered to the GAG-treated rats did not antagonize GAG produced synchronization, but rather facilitated it as expressed by the intensification of the abnormalities in the EEG. It was anticipated that picrotoxin would increase the severity of the kindled convulsions that had been attenuated by GAG. However, the seizure intensity produced by amygdala stimulation delivered during the picrotoxin sedation period (stage 1) was further attenuated in the three animals that were still showing some seizures. In three other GAG-treated animals that were not showing any seizures, no effect of picrotoxin could be detected.

\section{DISCUSSION}

The present findings demonstrate that the GABA-T inhibitor, GAG, may significantly attenuate or totally suppress the motor convulsions produced by amygdala kindling. An increase in the GABAergic brain levels seems to have a less consistent effect on the amygdaloid seizure afterdischarge. Particularly on the first test after GAG injection, but also during the recovery period after the termination of drug treatment, there tended to be a dissociation of afterdischarge duration from the intensity of the seizure. On the first post-GAG test the afterdischarge duration was often increased or unchanged even where motor convulsions were totally suppressed. In a few instances, however, the afterdischarge duration did decrease on the first post-drug test.
A similar dissociation between motor convulsions and EEG produced by GAG was found in the total suppression of myoclonic responses in photosensitive baboons at a time when the EEG continued to show abnormal epileptiform activity (Meldrum and Horton, 1978).

This partial dissociation of the electrographic seizure from its behavioral accompaniment is hardly a result of the myotonolytic effect that GABA agonists are known to possess (Carlidge et al., 1974; Feldman et al., 1978). When the duration of the electrical stimulation was increased, it proved possible to induce motor seizures that appeared identical, electrophysiologically and behaviorally, to the original seizures observed before to GAG treatment.

This dissociation between the behavioral and EEG manifestations of seizures is difficult to explain. The phenomenon seems to violate the "all-or-none" principle described for mature kindled seizures (Sato and Nakashima, 1975; Wada and Sato, 1975). The maturation of the kindling process is generally believed to depend on the gradual buildup of the stimulation-induced afterdischarges (Racine, 1972). With continuation of stimulation the motor accompaniment gradually reaches the magnitude of stage 5 convulsions, a process thought to indicate that kindling "strengthens" or "creates" the output to the motor system (Goddard and Douglas, 1975). The ability of this process to "regress" under the GAG treatment condition may imply that the connections to the output apparatus are controlled or modulated by inhibitory GABA neurons. Similarly, other compounds such as diazepam and phenobarbital, which are reported to produce afterdischarge behavior dissociation (Wise and Chinerman, 1974), may also act through a GABAergic system. Diazepam is known to mimic both pre- and postsynaptic effects of GABA (see Costa, 1977, for review) and it has been suggested that benzodiazepines produce an allosteric alteration of the 


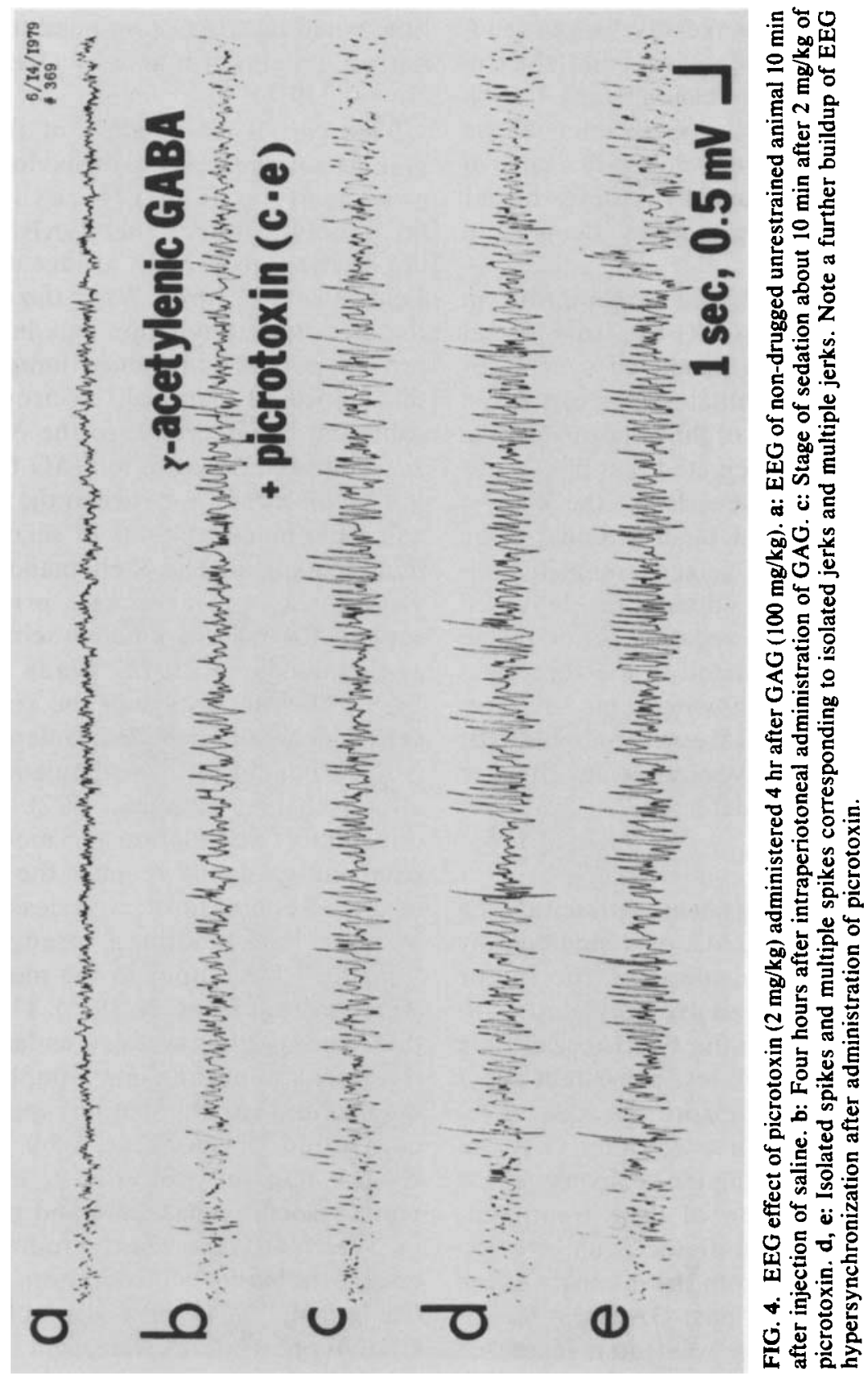


GABA binding sites that increases the effectiveness of the GABA action (Guidolli et al., in press; cited by Kupferman, 1979). Barbituates also potentiate GABA effects (Nicoll, 1978; Ransom and Baker, 1976) and reverse GABA effects blocked by its antagonist, bicuculine (Bowery and Dray, 1976).

In spite of the evidence implicating GABA in the expression of behavioral seizures there remain problems for interpreting the present results with amygdala kindling. Although GABA is an omnipresent amino acid, the largest amounts of this neurotransmitter are found in the mesencephalon, neostriatum, and hippocampus, but not in the amygdala (McGeer et al., 1978). A relatively high content of glutamic acid decarboxylase, however, has been found in the amygdaloid complex (Le Gal La Salle et al., 1978). In addition, the findings of the same authors suggest that there is a GABAergic amygdalopetal component within the stria terminalis projecting to the central, amygdala nucleus although the source of these fibers remains unknown. Given this uncertainty, and the systemic route of GAG administration employed in the present study, it is not possible to ascribe the effects observed to any particular GABA pathway, or mechanism.

Catecholamines are also possible candidates for such GABA-mediated effects. They are implicated in epilepsy (see Maynert et al., 1975) and have a close relationship with the GABAergic system. They also are known to act as endogenous antiepileptic compounds in some forms of epilepsy due to their participation in high arousal states, known to impede seizures. Paradoxically, however, GAG has a powerful anti-seizure effect on a background of visible arousal decrement as evidenced by the decreased motility in rats, EEG synchronization, and even hypersynchronization (Myslobodsky et al., 1979; Valenstein and Myslobodsky, in preparation). A decrease in arousal level, somnolence, and slow-wave sleep are known to facilitate interictal amygdaloid spiking in kindled animals (Tanaka et al., 1975).

A number of GABAergic compounds have a distinct soporific effect (Anden et al., 1973; Roberts and Simonsen, 1966; Scotti de Carolis and Massotti, 1978) similar to GAG. This phenomenon is not well understood although it is often interpreted as indicating the ability of GABA to control the activity of dopamine-containing neurons, with corresponding decrease in dopamine turnover rate. Recently, Palfreyman et al. (1978) reported a decrease in homovanillic acid in the striatum, but not in the nucleus accumbens, after administration of $100 \mathrm{mg} / \mathrm{kg}$ of $\mathrm{GAG}$, suggesting that GAG decreases striatal dopamine turnover. It is well known, however, that the neostriatum has an inhibitory effect on amygdaloid seizures (Fariello, 1976; La Grutta et al., 1971), whereas accumbens stimulation generally has no detectable effect (Fariello, 1976). Therefore, if dopamine is involved in epilepsy control (see Maynert et al., 1975), its role in suppressing kindled seizures seems obscure in view of these findings. Some indications of the facilitation of the kindling process after stria terminalis lesions (Engel and Katzman, 1977) may be interpreted (Le Gal La Salle et al., 1978) as related to the loss of GABAergic, but not dopaminergic, control over amygdala neurons.

The other catecholamine, norepinephrine, is also known to interfere with convulsive disorders in general (Maynert et al., 1975) and with kindled seizures in particular (Corcoran et al., 1974). The norepinephrine neurons of the locus coeruleus project to practically all divisions of the amygdaloid complex (Fallon et al., 1978). In addition, the turnover of norepinephrine in the central nervous system reportedly has been facilitated by GABA under in vivo conditions in the rat (Biswas and Carlsson, 1977). These GABA effects on norepinephrine transmission are not affected by picrotoxin 
(Biswas and Carlsson, 1977a,b), which is consistent with the present findings that picrotoxin is unable to antagonize the GAG-inhibited seizures. Therefore, it is possible that the increase in GABAergic levels leads to seizures suppression through the mediation of the dorsal norepinephrine system, although this remains to be proven.

\section{Effect of Picrotoxin}

Being an inhibitory transmitter, GABA is probably involved in the generation of the "inhibitory synchronous activity." In fact, sleep spindles (Andersen and Andersson, 1968 ), certain categories of delta waves (Ball et al., 1977), sensory theta activity in rodents (Guselnikov and Supin, 1968), "pleasure rhythms," and wave-spike discharges (Myslobodsky, 1976; see also for review) are all supposedly organized due to a phasing of depolarizing potentials with the long lasting waves of postsynaptic inhibition. Since picrotoxin activates a similar type of EEG hypersynchronization as found with GAG, the effects of the two compounds must have summated. Although this hypersynchronization was currently seen to facilitate spiking in the amygdala as was also reported in natural sleep (Tanaka et al., 1975), it seemingly antagonizes actual seizures, that is, selfsustained afterdischarges. A conceivable analogy to this effect is the increased threshold for grand mal seizures during slow-wave sleep and the decrease during REM sleep. In fact, high frequency electrical stimulation that produces an arousal reaction reportedly reduces the latency of - kindled grand mal convulsions (Tanaka et al., 1975) whereas $d$-amphetamine tends to prolong amygdaloid convulsions (Babington and Wedeking, 1973). The nature of this effect is discussed at length elsewhere (Myslobodsky, 1976) and is mentioned here to emphasize that although picrotoxin and GAG produce an epileptiform-like EEG pattern it may in fact hyperpolarize the same pool of neurons that need to be depolarized by amygdaloid electrical stimulation to induce selfsustained afterdischarges.

Another problem requiring discussion is why picrotoxin, a compound long known to antagonize GABAergic transmission, should not eliminate rather than potentiate the sedation and wave-spike activity induced by GAG. A likely explanation of this effect stems from the fact that whereas picrotoxin acts presynaptically, the data suggest that GABA mediates both pre- and postsynaptic inhibition (Roberts et al., 1970). These facts invite the speculation that whereas increases in GABA levels produce synchronization and somnolence predominantly by postsynaptic action, picrotoxin may exaggerate the activity of postsynaptic inhibition by blocking GABAmediated depolarization on the terminal branches of inhibitory interneurons.

Although attractive, this proposed explanation of the potentiation of GAG effects by picrotoxin rests on several assumptions. First, the hypothesis depends on the existence of synaptic inhibitory synapses localized on the terminals of inhibitory neurons. Although picrotoxin has long since been implicated in presynaptic inhibition (see Levy, 1977 for review) there is no direct evidence in support of this assumption. It should be noted, however, that there are precedents for this type of mechanism. For example, "inhibition of inhibition" is believed to operate in the visual cortex (Skrebitsky, 1967), neostriatum (Buchwald et al., 1967), and thalamus (Purpura et al., 1966).

In addition, the hypothesis requires that postsynaptic inhibition should be relatively more powerful in the brain than presynaptic inhibition. In the opposite case, the effect of the GABA level increase at postsynaptic sites would be opposed by the parallel increase in potency of the presynaptic inhibition operating on the output of the inhibitory interneurons, and the net result of GAG would be insignificant. There is little 
direct evidence available, but some support for our hypothesis may be derived from the belief that although presynaptic inhibition has an important role in the thalamus, it is generally far less effective at the higher levels of the brain than in the spinal cord (see McGeer et al., 1978).

Finally, the ability of picrotoxin to potentiate EEG and behavioral effects of GAG suggests that there may be at least two types of GABA receptors, only one of which is blocked by picrotoxin, as was recently suggested by Krnjevic (1971). Alternative possibilities are that picrotoxin could have partial GABA agonistic activity. In any event, the results of these experiments would appear to justify the further analysis of picrotoxin effects on kindled seizures.

\section{Practical Implications}

These findings along with recently reported data on the beneficial effects of GAGA treatment in audiogenic epilepsy, alcohol withdrawal epileptiform syndrome, and photosensitive epilepsy (see introductory section) suggest that this compound has important antiepileptic properties that should attract the attention of epileptologists. As a note of caution one should remember that GAG-produced EEG hypersynchronization may reach an undesirable magnitude and interfere with arousal level and performance of the subjects (Valenstein and Myslobodsky, submitted).

\section{ACKNOWLEDGMENT}

The authors are pleased to acknowledge the generous gift of $\gamma$-acetylenic GABA by the Merrell National Laboratories, Cincinnati, Ohio.

\section{REFERENCES}

Anden NE, Dalen, and Johansson B. Baclofen and lithium in Huntington's Chorea. Lancet 2:93, 1973.

Andersen P and Andersson SA. Physiological Basis of Alpha-Rhythm. Appleton-Century-Crofts, New York, 1968.

Babington RG and Wedeking PW. The pharmacology of seizures induced by sensitization with low inten- sity brain stimulation. Pharmacol Biochem Behav 1:461-467, 1973.

Ball GJ, Gloor P, and Schane N. The cortical electromicrophysiology of pathological delta waves in the electroencephalogram of cats. Electroencephalogr Clin Neurophysiol 43:346-361, 1977.

Biswas $B$ and Carlsson A. The effect of intracerebroventricularly administered GABA on brain monoamine metabolism. Naunyn Schmiedeberg's Arch Pharmacol 299:41-46, 1977a.

Biswas $B$ and Carlsson A. The effect of intraperitoneally administered GABA on brain monoamine metabolism. Naunyn Schmiedeberg's Arch Pharmacol 299:47-51, $1977 b$.

Bowery NG and Dray A. Barbiturate reversal of amino acid antagonism produced by convulsant agents. Nature 264:276-278, 1976.

Buckwald NA, Hull CD, Trachtenberg MC. Concomitant behavioral and neural inhibition and disinhibition in response to subcortical stimulation. Exp. Brain Res 4:58-72, 1967.

Carlidge NE, Hudgson P, and Weightman D. A comparison of baclofen and diazepam in the treatment of spasticity. J Neurol Sci 23:17-24, 1974.

Cooper BR, Viik K, Ferris' RM, and White HL. Antagonism of the enhanced susceptibility to audiogenic seizures during alcohol withdrawal in the rat by $\gamma$-aminobutyric acid (GABA) and "GABAmimetic" agents. J Pharmacol Exp Ther 209:396-403, 1979.

Corcoran ME, Fibiger HC, McCaughran JA, and Wada JA. Potentiation of amygdaloid kindling and metrazol-induced seizures by 6-hydroxydopamine in rats. Exp Neurol 45:118-133, 1974.

Costa $E$. Some recent advances in the biochemical pharmacology of $\gamma$-aminobutyric acid. In: Usdin $E$, Hamburg DA and Barchas JD (Eds), Neuroregulators and Psychiatric Disorders, Oxford University Press, New York, 1977, pp. $372-378$.

Engel $J$ and Katzman $R$. Facilitation of amygdaloid kindling by lesions of the stria terminalis. Brain Res 122:137-142, 1977.

Fallon JH, Koziell DA, and Moore RY. Catecholamine innervation of the basal ganglia. II. Amygdala, suprarhinal cortex and autorhovel cortex.J Comp Neurol 80:509-532, 1978.

Fariello R. Forebrain influences on the amygdaloid acute focus in the cat. Exp Neurol 51:515-528, 1976.

Feldman RG, Kelly-Hayes M, Conomy JP, and Foley JM. Baclofen for spasticity in multiple sclerosis. Neurology 28:1094-1098, 1978.

Goddard GV. Development of epileptic seizures through brain stimulation at low intensity. Nature 214:1020, 1967.

Goddard GV and Douglas RM. Does the engram of kindling model the engram of normal long term memory. Can J Neurol 2:385-394, 1975.

Guselnikov VI and Supin AY. Rhythmical Activity of the Brain. Moscow University Press, Moscow, 1968.

Jung MJ, Lippert B, Metcalf BW, Schechter PJ, Böhlen $P$, and Sjoerdsma $A$. The effect of 4-amino 
Hex-5-ynoic acid ( $\chi$-acetylenic GABA, $\gamma$-ethynyl GABA) a catalytic inhibitor of GABA transaminase, on brain GABA metabolism in vivo. $J$ Neurochem 28:717-723, 1977a.

Jung MJ, Lippert B, Metcalf BW, Böhlen P, and Schechter PJ. $y$-Vinyl-GABA (4-amino-hex-5enoic acid), a new selective irreversible inhibitor of GABA-T: Effects on brain GABA metabolism in mice. $J$ Neurochem 29:797-802, $1977 b$.

Krnjevic K. Effects of drugs on inhibitory synapses. In: Advances in Cytopharmacology, Vol. I. In: Clementi B and Ceccarelli B (Eds.) First International Symposium on Cell Biology and Cytopharmacology. Raven Press, New York, 1971, pp. 419-426.

Krnjevic K. Chemical nature of synaptic transmission in vertebrates. Physiol Rev 54:418-540, 1974.

Kupfermann I. Modulatory actions of neurotransmitters. Am Rev Neurosci 2:447-465, 1979.

La Grutta V, Amato G, and Zagam MT. The importance of the caudate nucleus in the control of convulsive activity in the amygdaloid complex, and temporal cortex in the cat. Electroencephalogr Clin Neurophysiol 31:57-69, 1971.

Le Gal La Salle G, Paxinos G, Emson P, and Ben-Ari $Y$. Neurochemical mapping of GABAergic systems in the amygdaloid complex and bed nucleus of the stria terminalis. Brain Res 155:397-403, 1978.

Levy RA. The role of GABA in primary afferent depolarisation. Prog Neurobiol 9:211-267, 1977.

Maynert EW, Marczynski TJ, and Browning RA. The role of the neurotransmitters in the epilepsies. In: Friedlander WJ (Ed), Advances in Neurology, Raven Press, New York, 1975, pp. 79-147.

McGeer PL, Eccles Sir JC, and McGeer EG. Molecular Neurobiology of the Mammalian Brain. Plenum Press, New York, 1978.

Meldrum BS. Epilepsy and GABA-mediated inhibition. Int Rev Neurobiol 17:1-36, 1975.

Meldrum B and Horton R. Blockade of epileptic responses in the photosensitive baboon, papio papio, by two irreversible inhibitors of GABA-transaminase, $\gamma$-acetylenic GABA (4-amino-hex-5-ynoic acid) and $\gamma$-vinyl GABA (4-amino-hexeno acid). Psychopharmacology 59:47-50, 1978.

Myslobodsky M. Petit Mal Epilepsy: A Search for Precursors of Wave-spike Discharges. Academic Press, New York, 1976.

Myslobodsky MS, Ackermann RF, and Engel J. Effects of $\gamma$-acetylenic GABA and $\gamma$-vinyl GABA on metrazol-activated, and kindled seizures. Pharmacol Biochem Behav 11:265-271, 1979.

Nicoll RA. Phentobarbital: Differential postsynaptic action on sympathetic ganglion cells. Science 199:451-452, 1978.

Palfreyman MG, Huot S, Lippert B, and Schechter PJ. The effect of $\gamma$-acetylenic GABA, an enzymeactivated irreversible inhibitor of GABAtransaminase on dopamine pathways of the extrapyramidal and limbic systems. Eur $J$ Pharmacol 50:325-336, 1978.

Purpura DP, McMurtry JG, and Maekawa K. Synaptic events in ventrolateral thalamic neurons curing suppression of recruiting responses by brain stem reticular stimulation. Brain Res 1:63-76, 1966.
Racine RJ. Modification of seizure activity by electrical stimulation. II. Motor seizure. Electroencephalogr Clin Neurophysiol 32:281-294, 1972.

Ransom BR and Baker JL. Phenobarbital selectively enhances GABA-mediated postsynaptic inhibition in tissue cultured mouse spinal neurons. Brain Res 114:130-135, 1976.

Roberts E, Kuriyama K, and Haber B. Biochemistry of synaptic inhibition at the cellular level: The GABA system. In: Costa E and Giacobini E (Eds), Advances in Biochemical Psychopharmacology, Raven Press, New York, 1970, pp. 131- 167.

Roberts E and Simonsen DG. A hypnotic and possible analgesic effect of imidazoleacetic acid in mice. Biochem Pharmacol 15:1875-1877, 1966.

Sato $M$ and Nakashima T. Kindling: Secondary epileptogenesis, sleep and catecholamines. Can J Neurol Sci 2:434-446, 1975.

Schechter PJ, Tranier Y, Jung MJ, and Böhlen P. Audiogenic seizure protection by elevated brain GABA concentration in mice: effects of $\gamma$ acetylenic GABA and $\gamma$-vinyl GABA, two irreversible GABA-T inhibitors. Eur I Pharmacol 45:319-328, $1977 a$.

Schechter PJ, Tranier Y, Jung MJ, and Sjoerdsma A. Antiseizure activity of $\gamma$-acetylenic $\gamma$-aminobutyric acid: A catalytic irreversible inhibitor of $\gamma$ aminobutyric acid transaminase. I Pharmacol Exp Ther 201:606-612, $1977 b$.

Scotti de Carolis A and Massotti M. Electroencephalographic and behavioral investigations on "gabaergic" drugs muscimol, baclofen and sodium $\gamma$-hydroxybutyrate. Prog Neuropsychopharmacol 2:431-442, 1978.

Skrebitsky VG. Inhibition of inhibitory postsynaptic components of the visual evoked potentials during auditory stimulus presentation. $Z$ Viss Nerun Dejat 17:158-168, 1967.

Tanaka T, Lange $H$, and Naquet $R$. Sleep, subcortical stimulation and kindling in the cat. Can J Neurol Sci 2:447-455, 1975.

Valenstein ES and Myslobodsky MS. An inability of $\gamma$-acetylenic GABA and picrotoxin to block eating evoked by hypothalamic stimulation. Submitted.

Wada JA. Pharmacological prophylaxis in the kindling model of epilepsy. Arch Neurol 34:389-395, 1977.

Wada JA and Sato M. Generalized convulsive seizures induced by daily electrical stimulation of the amygdala in cats. Neurol (Minn.) 24:565-574, 1974.

Wang JC and Ward JW. Analeptics. Pharmacol Ther Bull 3:123-165, 1977.

Wise RA and Chinerman J. Effects of diazepam and phenobarbital on electrically-induced amygdaloid seizures and seizure development. Exp Neurol 45:355-363, 1974.

Wood JD, Durham JS, and Peesker SJ. Effect of di- $n$ propylacetate and $\gamma$-acetylenic GABA on hyperbaric oxygen-induced seizures and GABA metabolism. Neurochem Res 2:707-715, 1977.

\section{RÉSUMÉ}

L'effet de l'élévation des taux cérébraux de GABA sur les crises amygdaliennes par effet d'embrasement complet a été étudié chez des rats Long-Evans. L'in- 
jection pendant 4 jours consécutifs de $100 \mathrm{mg} / \mathrm{kg}$ suivis de $50 \mathrm{mg} / \mathrm{kg}$ i.p. d'un inhibiteur de la GABA. Transaminase nouvellement synthétisé ( $y$-acetylenic GABA ou GAG) a significativement réduit ou même supprimé les crises normalement provoquées par la stimulation amygdalienne. L'effet est observé après la première injection de GAG, mais son importance s'accroit les jours suivants. Les crises réapparaissent 2 ou 3 jours après la fin du traitement au GAG. Du point de vue électrographique, la durée de la postdécharge amygdalienne autoentretenue est inchangée ou accrue le premier jour du traitement, mais elle diminue les jours suivants pour retourner a la normale un ou deux jours avant que les crises ne réapparaissent après la fin de l'administration du GAG. L'injection de picrotoxine $(1.5-2 \mathrm{mg} / \mathrm{kg}$ i.p.) ne s'oppose pas aux effets inhibiteurs du GAG sur les crises ou leur accompagnement EEG. La stimulation électrique de l'amygdala pendant l'étape sédative initiale induite par la picrotoxine provoque une régression supplémentaire des crises d'embrasement chez la majorité des animaux. Bien que, aux doses utilisées, le GAG atténue les crises amygdaliennes d'embrasement, son utilisation nécessite des précautions compte tenu de sa tendance à réduire le niveau d'éveil.

\section{(J. L. Gastaut, Marseilles)}

\section{RESUMEN}

En ratas Long-Evans se ha investigado el efecto del aumento de los niveles cerebrales de GABA, sobre los ataques originados en la amígdala totalmente condicionada, (Kindling). El recientemente sintetizado inhibidor de la GABA transaminasa, $\gamma$-acetilénico GABA (GAG), redujo significativamente o eliminó totalmente las crisis de comportamiento que habitualmente se producen con la estimulación de la amígdala. El efecto se observa después de la primera inyección de GAG pero su magnitud aumentó en dias subsiguientes. Las crisis de comportamiento reaparecieron a los 2-3 días de la interrupción del tratamiento con GAG. La duración de los ataques electrográficos (perservación de la post-descarga de la amígdala) no se modificó, o incluso aumentó, en el primer dia de la administración de GAG pero se redujo en los dias siguientes. La duración de las postdescargas volvió a sus niveles normales 1 o 2 dias antes que la reaparición de las crisis de comportamiento una vez terminado el tratamiento con GAG.
La picrotoxina (1.5-2 mg/kg, i.p.) no antagonizó los efectos inhibitorios producidos por el GAG sobre el electroencefalograma o las crisis de comportamiento. La estimulación eléctrica sobre la amígdala, aplicada durante la fase de sedación inicial inducida por la picrotoxina, condujo a una regresión aún más intensa de las crisis condicionadas, en la mayoría de los animales. A pesar de que, con las dosis utilizadas, el GAG alivia las crisis de la amigdala previamente condicionada, se requiere gran precaución en su utilización en vista de su propiedad de reducir el nivel del despertar.

(A. Portera Sanchez, Madrid)

\section{ZUSAMMENFASSUNG}

Die Wirkung erhöhter GABA-Spiegel des Gehirns auf Amygdalonkrämpfe nach Kindling wurden bei Long-Evans-Ratten untersucht. Der neuerdings synthetisierte GABA-Transaminasen-Inhibitor, GammaAcetylen-GABA (GAG) wurde an 4 aufeinanderfolgenden Tagen in einer Dosis von $100 \mathrm{mg} / \mathrm{kg}$ und anschließend $50 \mathrm{mg} / \mathrm{kg}$ i.p. verabfolgt. Er reduzierte entweder signifikant oder eliminierte völlig die anfallsweisen Verhaltensänderungen, die normalerweise durch Stimulation des Amy'gdalon produziert wurden. Die Wirkung ist nach der Erstinjektion des GAG zu beobachten, obgleich ihr Ausmaß an folgenden Tagen größer war. Die Verhaltensanfälle kamen 2 bis 3 Tagen nach Beendigung der GAG-Behandlung wieder.- Die Dauer der elektrographischen Anfalle (sich selbst unterhaltende Amydalonnachentladungen) blieben entweder gleich oder sie wurden größer am 1. Tag der GAG-Behandlung, wurden aber kürzer an folgenden Tagen. Die Dauer der Nachentladungen normalisierte sich 1 bis 2 Tage früher als die Verhaltensanfälle nach Beendigung des GAG verschwanden. Picrotoxin (1.5 bis $2 \mathrm{mg} / \mathrm{kg}$ i.p.) wirken nicht als Antagonist gegenüber der durch GAG produzierten Hemmung der elektrographischen-oder Verhaltenseffekte. Die elektrische Stimulierung des Amygdalon während der initialen Sedierung nach Picrotoxin verursachte bei der Mehrzahl der Tiere einen weiteren Rückgang der durch Kindling entstandenen Anfälle. Obgleich das GAG in den verwandten Dosen, die durch Kindling des Amygdalon erzeugten Krämpfe leichter ablaufen läßt, erfordert seine Anwendung Vorsicht hinsichtlich seiner Fähigkeit, das Erregbarkeitsniveau zu senken.

(D. Scheffner, Heidelberg) 